\title{
SOME BALKAN AND DANUBIAN CONNEXIONS OF TROY.
}

PreHistoric research shows us that in the troubled section of Europe known as the Near East there existed as early as the neolithic period several culture groups which may be classified under four heads as follows:-

(1) The Aegean, Minoan-Mycenaean group.

(2) The Thessalian.

(3) The Upper Balkan and Danubian.

(4) The South Russian and allied groups.

The first of these is so familiar that we need only emphasize its continuity from the neolithic period through the Bronze Age, and the fact that, although eventually it was widely diffused through the Mediterranean from Spain to Cyprus and the coast of Palestine, in the Aegean area itself the northern limit on the west coast was Thessaly, which it reached in the L. M. period, and on the opposite shore the single site toward the north is Troy, where L. M. is contemporary with the VIth city. The sporadic examples on the coast from Thessaly to Troy are very late and apparently had little influence.

The excavations by Messrs. Wace and Thompson in prehistoric Thessaly, which included considerably more than one hundred sites, have led them to differentiate a large number of styles of pottery, including red monochrome, red or black incised, or else painted either light on dark or dark on light in many varieties. ${ }^{1}$ The designs are predominantly rectilinear and more closely akin to the northern groups than to the Minoan. These styles extend from the Neolithic, through Chalcolithic to the Bronze Age, with gradual changes and no violent break until the close of L. M. III. This tallies with what had already been known of Minoan influence on the Thessalian coast. The terracotta figurines are also quite different from the island or Aegean type and belong to the short and stumpy styles of the mainland. ${ }^{2}$ The excavators believe that except for the Creto-Mycenaean vases (L. M. II. and III.) there seems to be hardly any direct connexion between Thessaly and the south-eastern regions of the mainland, neither did the Cycladic (Island) styles have much influence. 4 Even when at the close of the Minoan period

\footnotetext{
${ }_{1}$ Wace and Thompson, Prehistoric Thes- ${ }^{3}$ Ibid. p. 225. saly, pp. 13-23.

2 Ibid. p. 232.

4 Ibid. p. 226. 
that civilization came into contact with Thessaly, it did not replace the local wares but continued side by side with them and what influence there was resulted in a somewhat hybrid style. ${ }^{5}$

It is, therefore, not to the south but to the north that the excavators have looked for connexions with Thessaly. ${ }^{6}$

On the basis of a few sherds, one cup and one bowl, Dr. Tsountas is inclined to note a relationship between Thessaly and Troy, but Messrs. Wace and Thompson do not agree with this view and regard the Trojan vases as unlike the Thessalian in most respects.

The occurrence of Minyan ware at Troy VI. and VII. and in Thessaly need not prove any direct communication although it may be inferred. The origin of Minyan ware is still uncertain. ${ }^{7}$

The Thessalian pottery seems to be affiliated with the north Balkans through a ware which may possibly be of Macedonian origin.

Adequate information is not yet to hand about Macedonia, but so far the connexions of Thessaly lie northward. The figurines have their closest analogies in Thrace and the decorative motives of the Dhimini ware, a combination of spiral and geometric, unite Thessaly with Thrace, Roumania, Galicia, Bessarabia, and South Russia. ${ }^{8}$

Thessaly continued in the neolithic or sub-neolithic period when the Aegean and the Serbian-Troy areas had reached the Bronze Age. Troy, which was situated on very important trade routes (as we shall see later), was connected with the Anatolian district on the east, and on the west through Serbia with other parts of Europe, but Thessaly lay too far south for this line. ${ }^{9}$ She was also off the Mycenaean trade routes, thus forming an isolated sort of backwater between these two great metal-using areas, and serving as a buffer State to keep central and southern Greece protected against the Danubian peoples. Later on, when the Mycenaean people removed the barrier (by trade or conquest), ${ }^{10}$ or when the restlessness and pressure from the rear sent more and more invaders into the Greek peninsula, Thessaly was in their path and many of the northerners followed that route. In fact, in the days of the Achaeans, Thessaly was one of the

${ }^{5}$ Ibid. p. 227.

${ }^{5}$ Ibid. ch. xiv.

7 Mr. E. J. Forsdyke (J.H.S. 1914, pp. 126-156) regards it as a Trojan fabric, and suggests that Greece was once a Trojan province and that the Trojan War records a struggle for the possession of both sides of the Aegean. He believes that the power which kept the Minoans from the coast of Asia Minor was a people whose most formidable site was Troy.

This brilliant and interesting hypothesis can hardly be maintained since the Minyan ware has not been proven Trojan, there are no remains like the Trojan anywhere along the coast of Asia Minor, and the theory runs counter to a great deal of archaeological evidence both in the Cyclades and on the mainland of Greece.

Mr. V. G. Childe's study (J.M.S. 1915, pp. 196-207) of the stratification at sites in Phocis which show Minyan ware in all stages of development leads him to believe the vases were not imported from Troy. Neither does he believe in a Trojan conquest, but he thinks that Minyan ware, if made in Troy, could have been passed along via the northern Cyclades where some finds in Syra and Naxos similar to Troy II. - V. show that contact had been established.

8 Wace and Thompson, Prehistoric Thessaly, p. 232.

9 Ibid. p. 233.

10 Ibid. p. 249. 
great centres of the Hellenes, and it is quite possible that the shaggy Pheres and barbarous substratum which Homer suggests afford a real hint of internal wars. The contrast between north and south Greece which we find in Homer corresponds with the facts as far as we know them. An interesting by-product of the discussion of Thessalian civilization is a suggestion about the Pelasgians. There is no intention of entering on the Pelasgian controversy at this point particularly in the face of the most reasonable explanation made by Dr. Leaf," ${ }^{11}$ but if Pelasgian implies ancient, out-of-date and uncivilized, it well describes the Thessalian people, the barbarous Pheres, Magnetes and Centaurs. The crude remains, such as the ithyphallic and steatopygous figurines, point in this direction. It seems at any rate a great mistake to make Pelasgian equal Mycenaean as Professor Ridgeway does, for Wace and Thompson show that the most Pelasgian spots are exactly those which are the least Mycenaean. ${ }^{12}$

Father Browne ${ }^{13}$ mentions the fact that there is a gap in Homer's geography which corresponds to Macedonia and that the poet knows the Trojan-Thracian group and the Greek, but not that which comes between.

There is a corresponding blank spot in Homer's Asia Minor (all along the coast) explained as the probable possessions of the Hittites, whose power had been flourishing since Minoan days and had prevented the Cretan mariners from settling in numbers on that littoral. ${ }^{4}$

One need not suppose an equally powerful people on the Greek side of the Aegean, and Father Browne suggests that this north-western gap may indicate a thrust of barbarians whom the bards either did not know or preferred not to recognize.

I think if there is a blank spot in Homer's record it lies farther south, as Macedonia is accounted for by the Paeonian allies who formerly occupied more territory than they did in historical times. And while it is still premature to say much about Macedonia, the excavations tend to bridge over the gap between Thrace and Thessaly. Thessaly, rather than Macedonia, appears to have been the backward barbarous area. ${ }^{15}$

It is not, however, with the Aegean or Thessalian areas that this paper proposes to deal, but with the peoples who inhabited the Danube Valley and kindred regions.

In the interesting eleventh chapter of The Discoveries in Crete, Professor Burrows gives an admirable summary of the finds in certain districts of South Russia and its vicinity, an area which he compares to a triangle the base of which extends from Kiev to northern Bohemia, the western side

11 Leaf, Troy, A Study in Homeric Geography, ch. vii.

12 Wace and Thompson, Prehistoric Thessaly, ch. xvii.

${ }^{13}$ Browne, Handbook of Homeric Study", pp. $175,282$.

1* Hogarth, Ionia and The East, pp. 47, $101,102$.

15 According to Wace and Thompson (op. cit. App. I. p. 258) the Thessalian pottery connected with Moldavia belongs to Th. II., that connected with Serbia to Th. III. ; it is therefore possible that there was once connexion between the Thessalian and Moldavian areas and that later the Serbian style split this area and extended over to Troy. This would account for the degeneration in the later Thessalian periods and also at Cucuteni. 
through Austria to Trieste and Bosnia, the eastern through Podolia and Bessarabia into Roumania; an east-central line comes through Bukovina and Transylvania, a west-central line through Hungary into Serbia. The eastern line may be extended through Eastern Roumelia, Troy and Yortan in Mysia. $^{16}$

Not all the culture in this area is of exactly the same type, and it may be classified as indicated on the map (Fig. 1), which shows the close relation-

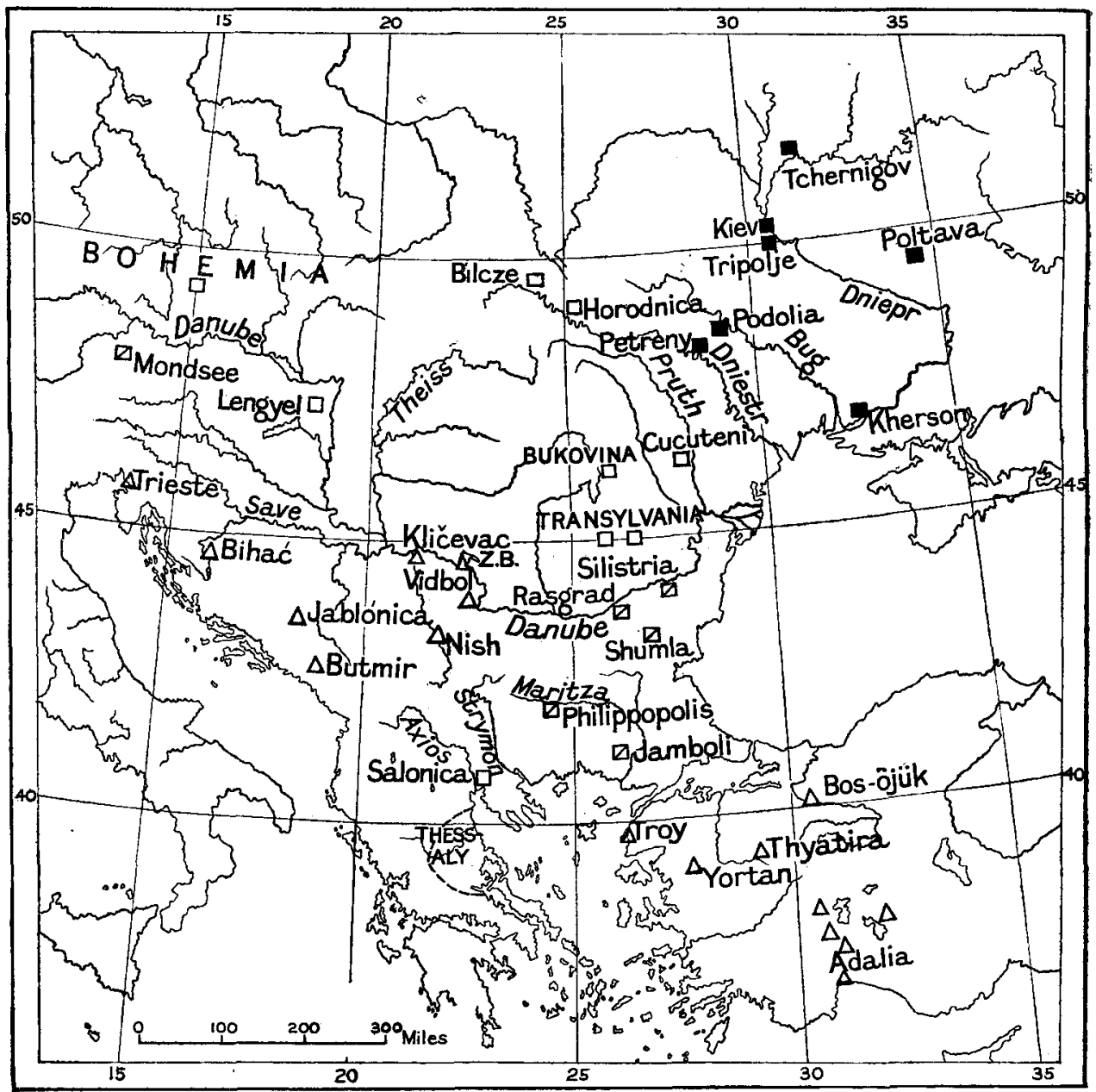

Fig. 1.-Distribution on Painted and Incised Wares. 1 ba

- Painted pottery of Kiev-Tripolje type.

口 Painted pottery of similar styles.

$\triangle$ Incised pottery.

■ Both painted and incised wares.

16 Burrows, The Discoveries in Crete, ch. xi. pp. 184, 185; Minns, Scythians and Greeks, pp. 132-142; Wace and Thompson, Cl. Rer.
1908, pp. 233-238.

16a Salonica should be marked $\square$. 
ship between Troy and the Balkan district in what Professor Myres has described as the Great Diagonal Line.

The first group, marked on the map by squares, shows the area of the remarkable polychrome painted pottery with spiral and naturalistic designs which belongs to the neolithic period, side by side with the incised fabrics which ordinarily characterize that age. This group may be further subdivided into:

(1) The Kiev-Tripolje culture, and

(2) The sites with pottery of similar styles.

The first is marked by solid squares, the others by hollow squares; those which lie furthest west have fewer points in common with Kiev than have the Galician sites.

The areas about Kiev, often described as the Tripolje culture (from Tripolje which is forty miles below Kiev on the Dniepr) are arranged in circular groups on high ground which slopes to the water on the south side. These areas were dug out to a depth of from two to four feet and are rectangular in shape, varying from five to ten yards in length and from six to eight in breadth, or occasionally as large as twenty by twelve. The walls were of wattle and clay, sometimes whitewashed and painted red or adorned with a cornice. The floor was apparently of hardened earth and the many lumps of clay which were strewn over it may have been parts of the roof. Amongst these clay fragments were found pottery of distinctive types to be described later, axes of horn or flint, sling stones, grinders, shells, bones of animals, tortoise shells, and small clay figures 'that distinctly recall those from Hissarlik.' ${ }^{17}$

Characteristic shapes of pottery are the opera-glass, and ccnical pots with a foot or with angular outline. Spirals or wavy patterns in ribbon-like effects are made by four or five parallel grooves or else painted in reddish or brownish colour on a yellow or red ground. ${ }^{18}$ Leaf designs are painted in brown on white or cream, and sometimes a light-coloured design is outlined in brown or black. ${ }^{19}$ The rare human figures recall the Dipylon style but are less attenuated. ${ }^{20}$ The figurines show progress from cruciform or slab-like idols to well rounded forms. Many have bird-like faces. ${ }^{21}$ Although most of the axes are of stone, copper is beginning to be used.

It seems improbable that these areas can have served as dwellings as there are no remains of food, discarded pottery, or a permanent hearth. Chvoika believed them to be tombs, although no bones have yet been found. Later discoveries, however, have furnished evidence of both cremation and inhumation. ${ }^{22}$

Podolia and Petreny belong to this group. One vase from Podolia represents goats, a deer and a $\operatorname{dog}$ on the upper zone. Others have backgrounds of black, light brown, yellow or grey with spirals and curves

17 Minns, op. cit. pp. 133-140 : Figs. 28, 31.

${ }^{18}$ Ibid. pp. 135-139 ; Figs. 29, 30, 32.

19 Ibid. Fig. 30. 
in white, red, orange or brown. ${ }^{23}$ The same colours and patterns occur at Petreny where in some cases the designs have been painted in black or violet brown on the natural red or yellow surface of the clay; in other instances there is a slip of red or brown (polished) or yellow or white (dull). Though the animals and human figures are not so good as at Tripolje or Podolia, the general effect must have been rich and varied. Knobs and small handles are found, but there is little incised work. ${ }^{24}$

This pottery may have been evolved in Russia or have been derived from elsewhere. Some scholars advocate an Aegean origin, but as far as one can judge from illustrations the resemblances are slight.

It seems rather strange that so much effort has been wasted in endeavouring to derive either the Aegean styles from the Russian-Danubian or vice versa. Both sides of the case have been well summarized by Professor Burrows, ${ }^{25}$ and the third view, namely, that of a parallel and independent development, is also presented. This is the view preferred by 1)r. Hoernes ${ }^{26}$ and Messrs. Wace and Thompson ${ }^{27}$ and appears the most reasonable explanation. Besides the fact that there is almost nothing common to the two except painted pottery and the spiral, there is the fact that between them there intervenes a fairly broad zone which includes Thessaly and the upper Balkans, each with rather distinctive styles of their own, and had this painted spiral motive passed through the Balkan peninsula either in a northward or southward direction, it surely would have left some traces. There remains the alternative of a sea-route, but insuperable objections to this are that few traces of Aegean civilization have been found on the coast anywhere between Volo and Troy, and no remains of Minoan pottery in South Russia or Thrace, and that it would have had to pass right through the Serbian-Trojan zone.

In any case, we find it superior in style to most other places in the neolithic period. As in Scandinavia the isolated position allowed fuller development of the neolithic technique in stone objects, so here the lateness of the knowledge of metal afforded the neolithic artists opportunity to develop the pottery which was their forte. Dates are hardly safe, or perhaps even desirable, but Nierderle's suggestion ${ }^{28}$ that it belongs to about 2000 B.C. seems a reasonable one. Of course the Aegean area had been using metal long before this, but there is no reason why even at the height of M. M. this district could not still have been in the stone age. While the origin is still obscure the affiliation is close with Transylvania and Galicia, where the sites at Bilcze Zlote ${ }^{29}$ and Horodnica ${ }^{30}$ furnish many beautiful examples of painted pottery in the Kiev style. These are described by Hoernes as

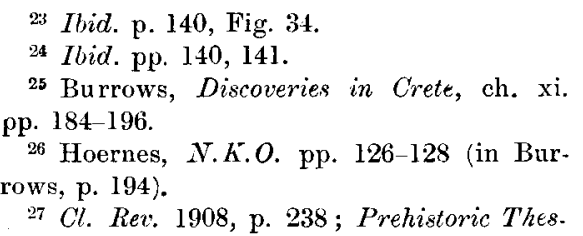

saly, p. 234 and Appendix I. pp. 257, 258.

28 Slav. Ant. i. p. 460, quoted in Minns, p. 142 .

29 Hoernes, Urgeschichte der bildenden Kunst in Europa, p. 291, Fig. 2 ; p. 315.

30 Ibid. p. 313. 
'Ukrainian' and include the characteristic opera-glass, the variations of spiral, and use the same rich colours. Another Galician site, Koszylowce, ${ }^{31}$ has grey incised pottery and painted ware. Its neolithic period is said to furnish many resemblances to the Thessalian and to afford a close parallel to Butmir.

In the Carpathian district or Transylvania, where both the incised and painted styles occur, Tordos and Kronstadt are two of the most fruitful sites. At 'Tordos the pottery designs are rectilinear and spiral, red or violet-red on a yellow-ground. In terracotta there are small short-legged animals and female idols with arms horizontally outstretched or placed on the body. ${ }^{32}$ Kronstadt ${ }^{35}$ furnishes many examples of pottery in which the straight and curved bands are drawn with great neatness and exactness. Although white on dark occurs, the converse technique is much more general. As at 'lordos there are many figures of animals and female idols, but the Kronstadt variety is very steatopygous and fat in the legs. The breasts are small, the navel and knee caps modelled in relief and the head often pierced through with holes. In Roumania Cucuteni (near Jassy) affords some good examples of polychrome styles. ${ }^{34}$ The earlier neolithic group includes a large number of the fruit-stand type whose shape and certain features of whose decoration recall the wares of Thessaly II., but are by no means identical and may easily be distinguished, since those from Cucuteni are dull and dusty while those from Thessaly are polished. The later vases which belong to the Chalcolithic or early Bronze Age recall those from Petreny in the use of spirals, and in the placing of the decoration on the upper part of the pots which slope rapidly to a small base.

The terracotta figures from Cucuteni are very striking; the upper part of the body seen in profile is flat and slablike, the head insignificant, and the steatopygy very marked; seen from the front or back they are broad shouldered and broad across the hips. They are covered with incised decorations, spiral and meander motives, curving lines, semi-circles and a peculiar arrangement giving the effect of drapery drawn very tight about the lower part of the body. ${ }^{35}$

These sites then furnish a group which, though not homogeneous, is closely affiliated. When we cross the Danube into Bulgaria we find connexions with Serbia and Bosnia and also with the group just described. ${ }^{36}$ There are incised wares with a combination of spiral and geometric designs, parallel lines in ribbon style, impressed chequer patterns and, less commonly, painted ware akin to the Moldavian and some use of graphite technique ${ }^{37}$ there are flat bone idols with incised decoration ${ }^{38}$ like the clay Ukrainian

\footnotetext{
${ }^{31}$ Hadaczek, Les Monuments archéologiques de la Galicie (review and summary in J.H.S. 1915 , p. 153).

32 Hoernes, op. cit. p. 305.

33 Ibid. p. 307, Figs. 4-8.

34 Wace and Thompson, Prehistoric Thessaly, p. 257.
}

${ }^{35}$ Hoernes, Urgeschichte, p. 299, Fiss. 1 and 2 .

${ }^{36}$ Seure and Degrand, B.C.H. 1906, pp. $359-432$, with 72 illustrations.

37 Wace and Thompson, Prehistoric Thessaly, p. 258.

38 B.C.H. 1906, p. 415, Fig. 57. 
idols, ${ }^{39}$ figurines reminiscent of the Cucuteni ${ }^{40}$ and Russian ${ }^{41}$ styles as well as seated figures covered with incised designs whose relationships cannot yet be determined. ${ }^{42}$ One rather interesting fragment of a terracotta shows the upper part of a bird, presumably an owl, whose eyes are ellipses with a straight line through the centre, the mouth a cross, the nose beaked, the plumage incised. It is suggested that it may be meant for a human being clad in an animal's skin, as we learn from Xenophon and Herodotus that the Thracians dressed in this fashion. ${ }^{43}$

Bulgaria then seems to have some relation to the Moldavian district north of the Danube and some with Serbia. Messrs. Wace and Thompson point out that in the Sofia museum are many weapons of the usual central European shapes. The bored celts which may imitate metal axes are characteristic of Troy as well and indicate a connexion between Troy and the central Danube valley, but as Troy affords no examples of Moldavian painted pottery the trade route probably branched off and followed the route taken later by the Roman road from Nish to the Hellespont. In Bulgaria the principal finds have been on the Danube at Rasgrad and near Silistria; in the Shumla district, at Jamboli and Tell Ratcheff near Jamboli; and at various sites near Philippopolis.44 In the Shumla district the painted Moldavian pottery is more frequent than near Philippopolis where incised wares are particularly plentiful. The wares of Ratcheff and Metchkur are, however, said by Messrs. Seure and Degrand to be almost identical, although the examples at the latter are a little more carefully done..5 These authors particularly note the resemblances to the Bosnian and Serbian fabrics.

The so-called Tomb of Protesilaus, two and and a half miles north of Sedd ul Bahr across the Hellespont from Troy, and the adjacent gardens were strewn with thick lustrous pottery characteristic of Troy I.; in the tomb were fabrics of Troy I. and II. styles, stone axes, hammers, querns and balls, a small bronze knife and baked bricks like those from the second and third Trojan cities. ${ }^{46}$ This was the only tumulus in which Trojan pottery was found by Schliemann, but later discoveries in Thrace and Bulgaria have furnished more examples. These help to confirm the statements of Herodotus and Strabo about the connexions between the Phrygians and Trojans and the migrations from southern Europe to Asia. Phrygians and Mysians had both taken the Bosporus route and had left at home in their native Thrace certain of their kinsmen known later as Bryges and Moesians. ${ }^{77}$ Quite probably the expansion of these tribes into North-western Asia Minor was part of the same movement which drove their kinsmen the Achaeans southward into the Groek

\footnotetext{
39 Hoernes, op. cit. p. 317, Figs. 1-3.

40 Ibid. p. 317, Fig. 4 (from Vidbol in the Vidin district).

${ }^{41}$ B.C.H. 1906, p. 390, Fig. 25; p. 391, Fig. 26 ; p. 414, Fig. 56.

42 Hoernes, p. 319 (from near Philippopolis); Wace and Thompson, Prehistoric Thessaly, p. 258; Wace and Thompson, Cl. Rev. p. 235, Fig. 4.
}

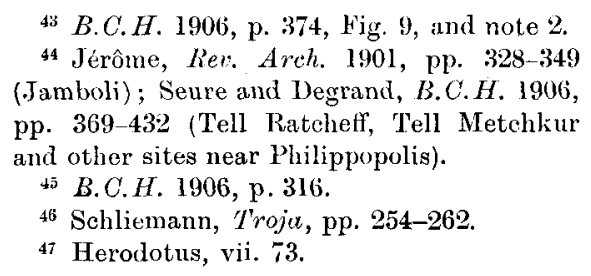
(Jamboli); Seure and Degrand, B.C.H. 1906, pp. 369-432 (Tell Ratcheff, Tell Metchkur and other sites near Philippopolis).

t̄̄ B.C.H. 1906, p. 316.

46 Schliemann, Irojex, pp. 254-262.

47 Herodotus, vii. 73. 
peninsula. ${ }^{48}$ The centre of distribution evidently lay somewhere in the district towards the Danube and the lines forked off from each other so that the Achaeans went southward to the west of the Phrygians. Strabo ${ }^{49}$ says also that the Phrygians passed from Thrace, killed the king of Troy . . . . . . and settled here, that there was much competition for the rich lands and that this had all happened before the Trojan War. Homer's Phrygian allies come chiefly from Asia Minor. The Phrygians seem to have had connexions to the south-westward also, as the Bryges belonged to Macedonia and according to Strabo ${ }^{50}$ the Paeonians were a colony of the Phrygians.

Bulgaria forms an easy transition to Group 4, the Bosnian-SerbianTrojan line (marked with a triangle). Here the pottery found with neolithic objects is not painted but incised or stamped, though the designs include spiral and curvilinear as well as rectilinear motives. Figurines of human beings are very plentiful; they are mostly female and commonly steatopygous. Bihac and Butmir represent the western extremities of this line, which extends through Serbia, particularly along the Danube as far as Radujevac, including the noteworthy sites of Klicevac and Zuto Brdo, and in the Morava valley as far as Nish. ${ }^{51}$ In this district Vinča and Jablanica are especially important stations. At Butmir the spiral, curved, straight or rectilinear designs are incised, dotted or stamped on the soft clay of the handmade pottery. Among the figures the simplest form is a slab-idol with outstretched stumps for arms; others end in pedestalled bases instead of arms, legs or feet. The necks are long, the faces inclined backward and have sharp noses, no chins, sloping foreheads, eyes with heavily ridged brows which often form a $\mathrm{T}$ with the nose. Incised patterns are frequent on the torsos, which are generally nude, although sometimes they seem to have a garment fitting tightly about the hips or are adorned with necklace and garlands in dots. ${ }^{22}$ At the Bosnian pile village of Ripač near Bihac and at Gresine on Lake Bourget have been found hermaphroditic terracottas, and at Ripač also pyramidal aniconic idols. ${ }^{53}$

In Serbia along the Morava valley there are remains of dwellings more or less rectangular in plan and constructed of wattle and clay. ${ }^{54}$ The incised designs on the pottery are both rectilinear and spirals, the closest affinities are with those of Butmir and the Pannonian group of Hoernes. Another favourite technique was decoration by impression or stamping and a third was 'highly polished black designs applied to the surface of the vase on the greyish-white slip' (evidently the graphite style). The incised decorations of the late periods are often filled in with white, ${ }^{55}$ e.g. Kličevac. Although the well-known figurine from Kličevac is familiar through illustrations, the significance of the site as a whole cannot be too frequently emphasized. ${ }^{56}$

\footnotetext{
48 Leaf, Homer and History, pp. 72, 73.

49 Strabo, xii. 8. 3, 4 .

in Itrid. Fr. 38.

51 Vassits, B.S.A. xiv. pp. $319 \mathrm{ff}$.

s. Hoemes, op. cit. pp. 2\$1, 283, 287, 289 (1-5).

J.H.S.-VOL. XXXIX.
}

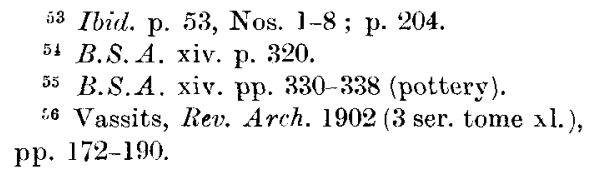


The red or black pottery incised and filled with white puts this site into connexion with places from Bosnia to Troy. Dr. Vassits is inclined to value it for the combination of what he identifies as geometric and Mycenaean elements although the spirals which he derives from Mycenae are characteristic of the very group marked with a triangle on the map.

The neighbouring site of Zuto Brdo ${ }^{57}$ is rich in figures with incised decorations and hand-made vases, dotted, stamped or incised in the usual style. While at Kličevac some metal occurs even in the lower strata, a true neolithic station is Jablanica ${ }^{59}$ which Dr. Vassits says stands in the same relation to Kličevac as pre-Mycenaean to Mycenaean. Even he sees no southern influence here and the affinities with the other sites in this group are remarkable, especially with Kubin in Hungary, Bosnia, Troy and Bos-Öjuik. This is clearly one of the most important sites which has yet come to light. Professor Myres ${ }^{59}$ regards it as a site of the utmost significance, enabling one to fill in a missing link between neolithic Butmir and Troy since hitherto there had been only the Thracian tumuli which were too near Troy to be really intermediate. M. Reinach ${ }^{60}$ calls it another link in the chain which connects Bosnia to the Troad and Phrygia, Hungary and Kiev. This he regards as a unified civilization with local differences, but thinks that an attempt at an ethnic name like Thraco-Illyrian or Phrygo-Scythian would be premature. It is with some diffidence that $I$ venture to disagree with this distinguished authority, but it seems to me that the difference in the two. groups is clearly marked, although there doubtless was contact between them.

The classification of about 1,000 statuettes in the Belgrade Museum shows that they extend from the earliest nude figures with flat triangular faces to the decadent type with bird's head and monstrous nose. Incision is plentifully used to mark the features, necklaces and clothing on the later examples. Standing figures wear a garment like two loin-cloths, square in cut, hanging from the belt, sometimes drawn like a sheath about the hips as at Cucuteni, or with ends hanging in front fastened to the belt with buttons which are represented by little clay knobs. Horizontal bands around the leg may represent boots. A fragmentary bone statuette recalls those from Bulgaria, Troy and Thessaly. ${ }^{\circ 1}$

The attempt made by Dr. Vassits to prove direct connexion between the Aegean and the Serbian cultures must be regarded as a failure; the affinities. of Serbia certainly seem to lie elsewhere. ${ }^{62}$

We may tabulate Groups 3 and 4 as follows:-

I. North of the Danube:

A. East of Carpathians :

1. (a) Kiev-Tchernigov-Tripolje-Poltava-Kherson in the Dniepr valley,

(b) Podolia-Petreny-in Dniestr,

\footnotetext{
57 Vassits, Rev. Arch. 1908 (4 ser. tome xi.), pp. 205-210.

${ }_{38}$ Vassits, Rev. Arch. 1902, p. 184; Archiv fïr Anthropologie, vol. 27 (1902), pp. 518-582.

:9 $M a n, 1905$, No. 41, pp. 78, 79.

60 Reinach, L'Anthropologie, 1901, pp. 527 ff.

o1 B.S.A. xiv. pp. 321-328.

62 Wace and Thompson, Cl. Rev. 1909, pp. $209-212$.
} 
2. Galicia (headwater of Dniestr), Cucuteni, Pruth, Bukowina, "

B. West of Carpathians :

1. Transylvania: Tordos,

Kronstadt.

2. Pamonian : Lengyel,

Attersee,

Mondsee,

Trieste.

II. In the Danube Valley or South of Danube:

1. Bosnian: Butmir,

Bihać.

2. Serbian: Danube,

Morava.

3. Bulgarian : Rasgrad, Silistria-on Danube,

Shumla,

Sultan Selo-Upper Maritza, W. branch, Jamboli-Upper Maritza, E. branch (Tundja), Philippopolis.

To sum up: to the north of the Danube the culture along the valleys of its tributaries like the Pruth and the Theiss is closely akin to that in the neighbouring river basins of the Dniepr and the Dniestr; on its southern side as well as along its tributaries the Save, the Drin and the Morava, the connexion is with the Bosnian group. Bulgaria seems to have been the meeting place of both civilizations.

But in order to discuss the connexions with Troy, where the remains of the second city afford many close resemblances to this fourth group (triangles. on the map), and where the Balkan-Danubian connexion becomes again evident in the seventh city of the Early Iron Age, we must consider the possible routes from the southern bank of the Danube to the Aegean area.

There are three of these, access to all of which is via the Morava. Following up this river to Nish one may go through the mountains and (1) down the Maritza, (2) down the Strymon or (3) across the watershed and down the Axios or Vardar. The first of these routes was taken by the Roman road and also by the Orient Express, and it leads into the parts of Bulgaria where remains have been discovered on both the upper branches of the Maritza as well as nearer to its mouth in the Aegean, whence there is an easy connexion with Troy. The Strymon route seems not to have been as. important as the others in ancient or modern times and the unsettled conditions in the country have made excavations impossible. It is not soaccessible from the headwaters of the Morava, but can be reached with little difficulty and is one of the natural outlets from near Sofia to the Aegean in spite of the elevation of the land through which it flows for part of its course. 
The map of present and projected railways ${ }^{63}$ shows that a road has been proposed through this valley.

We shall have to regard it as a route of secondary importance along which there is no good road even now, putting the Orient Express route and the Morava-Vardar route as the two really significant passageways. The Romans seem not to have utilised the Axios valley, which was natural enough as they were not so much concerned with north and south as with east and west. Their point of departure was Dyrrachium, thence north-east to Naissus and south-east to Byzantium, roughly two sides of a triangle the base of which was formed by the Via Egnatia, which went as nearly due east and west as the character of the country allowed. As far as Pella or Thessalonica it must have been an exceedingly difficult and uncomfortable journey, but east of the mouth of the Axios it followed the coast in the narrow strip lying south of Rhodope. For various reasons it seems that such a caravan route must have existed from a very remote period, or at any rate from the days of Homer, as we shall see.

The great Morava-Vardar route has been from time immemorial the corridor between the Danube and the Aegean, whether the tide of travel set from north to south, as in the case of the earliest invaders, or from south to north, as in the case of our allied armies. It would be absurd to think that the civilization which extended up the Morava stopped short at Nish and did not go down the other side of the mountains via the Axios. 'Macedonia,' to give it its old name, is sure to be a rich field for excavators, for the travels of Messrs. Wace and Thompson ${ }^{64}$ have brought to their notice a fairly large number of tumuli and settlements in the Salonica district alone. Their researches in Thessaly had fixed the Vale of Tempe as the northern boundary of the Thessalian culture, although sporadic examples of the wares had been found in Thrace. That northern boundary has now been pushed as far as the Haliacmon valley where sherds of Thessalian I. and II. were discovered at Serfije, while the investigations in the vicinity of Salonica make it probable that Macedonian culture partook of the character of its neighbours both to south (Thessaly) and to north (Danube-Balkan). In this neighbourhood they observed thirty-four funeral tumuli of a type unknown in south Greece but common in Thrace and extending also to Pergamon and to Kertch, and twenty-six prehistoric settlements furnish painted pottery which resembles the 'Thessalian II., III. and IV., as well as a thin spreading of L. M. III. of a type identified as mainland (not Cretan). There is also incised pottery of a simple geometric type, but according to Mr. Wace there was not enough of it to tell its relations to Thessaly, Thrace or Bosnia. ${ }^{65}$ These excavations are as yet unpublished ${ }^{66}$ and one must not draw premature

63 Newbigin, Geographical Aspects of Balkan Problems, Fig. 7, p. 103; Johnson, Topography and strategy of the War, ch. xiii.; Hogarth, The Nearer East, ch: xiii. p. 210, Fig. 44.
64 Wace and Thompson, Liverpool Annals, ii. (1909), p. 159 ff.; Wace, B.S.A. xx. pp. 123-132.

65 Wace, B.S.A. xx. p. 129.

of Carried on by Macridy Bey. 
conclusions, but we can at least connect Macedonia with Thessaly, Thrace, Serbia and Bosnia. ${ }^{67}$

Before considering the connexions between Troy and this area we may note that the Bosnian-Serbian line does not stop at Troy. Yortan on the upper valley of the Caicus in Mysia ${ }^{68}$ and Bos-Öjük near Phrygian Dorylaion on the Sangarius ${ }^{69}$ have furnished pottery similar to the Trojan, although some weapons of bronze show that the former site belongs to the Chalcolithic Age.

Mr. Ormerod's recent discoveries have added several sites which show some connexion with Troy and the Balkans. ${ }^{70}$ From Thyatira a seated female figurine with flat disc-like face and crossed bands on the breast recalls the lead figurine from Troy as well as one from Selendj (near Thyatira), and is even reminiscent of Bosnia, ${ }^{71}$ and three small vases with animals' heads and beaked forms are said to come from this vicinity. ${ }^{72}$ Further researches in northern Lycia, south-western Pisidia and southern Phrygia have supplied important material.

Tchai-Kenar ${ }^{73}$ near the Taurus is connected with both Troy and Cyprus by its pottery which includes burnished black, red-glazed and black-glazed incised wares which belong to the first and second cities at Hissarlik, and 'red Cypriote' painted ware of the early Iron Age. There is also some degenerate Mycenaean tradition and some non-Aegean influence which may perhaps have come via Cappadocia from the geometric areas of Western Asia. Two flat little headless tigures of coarse white marble from this vicinity are difficult to assign to any particular group, but perhaps belong to the Island type. ${ }^{74}$

On the basis of the pottery from Senirdje ${ }^{75}$ (near Isbarta in north Pisidia) which is chiefly dark grey burnished ware like that from Cyprus and Hissarlik in general style and shapes, decorated with broad, flat scorings, little lumps, or flutings, or rarely with incisions filled with white, the Hellespontine-North Phrygian area is extended further south-eastward. Similar pottery was found at Bounarbashi Giöl ${ }^{76}$ (near Apamea) together with five early bronze implements, two flat celts, two Cypriote daggers and one unfinished object, presumably a celt.

Other connexions are suggested by two small stone steatopygous figures. from Tchukurkend, ${ }^{77}$ as this type does not occur at Troy, or at Yortan (where the figures are flat), nor is it characteristic of the Aegean in spite of a few examples. It is, however, as we have seen, very common in south-west. Europe, Thrace and Thessaly.

\footnotetext{
67 See Professor E. A. Gardner in The Times Literary Supplement, March 29, 1918.

08 Burrows, op. cit. p. 185 (note 13).

${ }^{69}$ Koerte, Ath. Mitt. 1899, pp. 1-45; Pl. I. -IV.

${ }^{70}$ Ormerod and Woodward, B.S.A. xvi. pp. 76-136; Pls. VII., VIII.; Ormerod, B.S.A. xviii. pp. 80-94; Pls. V.-VII. ; B.S.A.
}

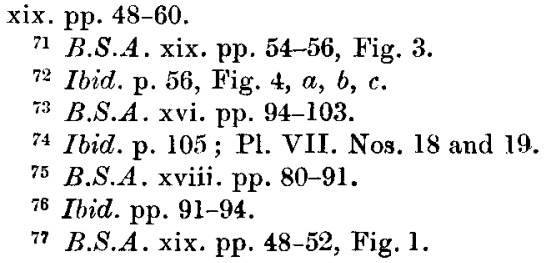


A flat, slablike torso of bucchero with crossed incised bands and punctured decoration from Kul Tepe near Caesarea recalls the Tchai-Kenar figure published by Mr. Peet, and the flat marble figures from Fulga in the Istanoz plain, and may be a crude example of the violin-shaped type found in the cyclades and Hissarlik and at Yortan. ${ }^{78}$

'To sum up: the line may be extended south-east on the evidence of the pottery and figurines while at the same time a counter-influence from Cyprus was making itself felt. We are hardly yet in a position to tell which came first. Certainly the Cypriote influence continued into the Iron Age. Dr. Leaf ${ }^{79}$ when discussing the Lycians among the Trojan allies, lays great stress on their commerce, which he believes was carried on principally by sea (see Map, Fig. 2), but for other purposes the overland route was doubtless

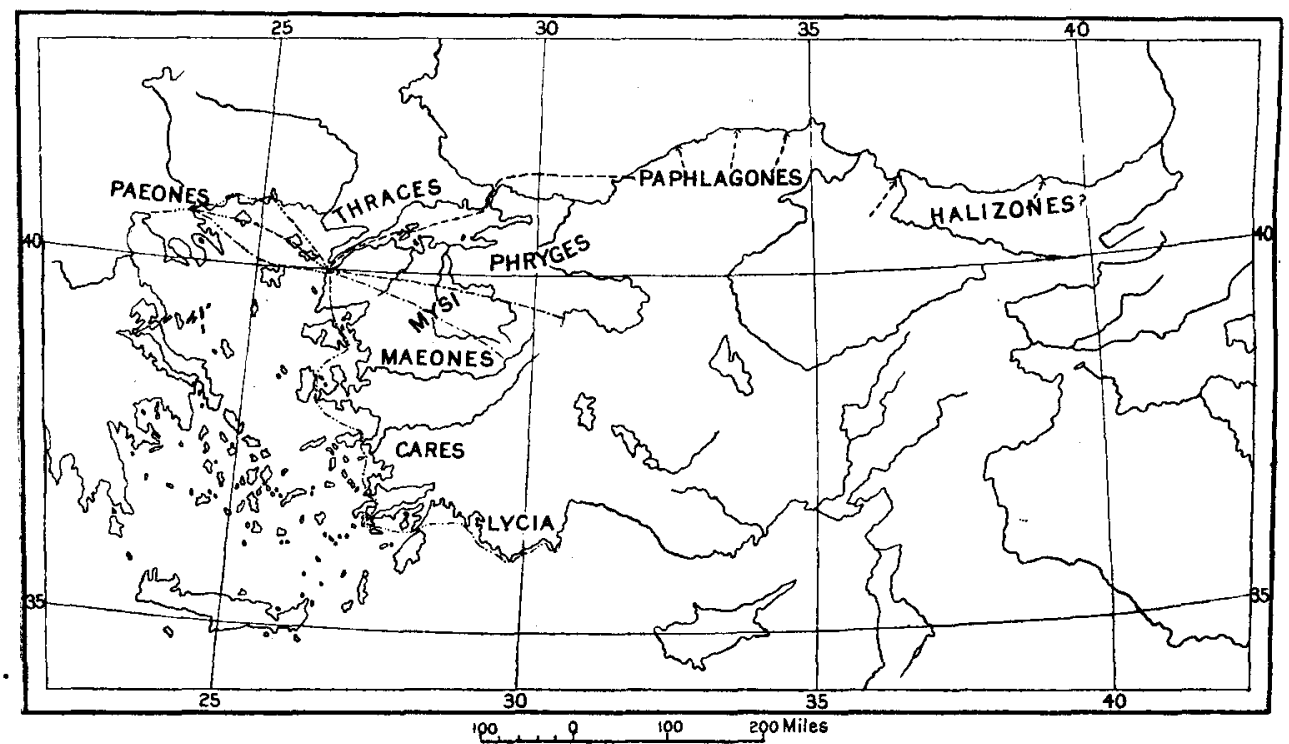

Fig. 2.-Trade Routes Converging on Troy.

(1) Paphlagonians and Halizones -

(2) Mysians and Phrygians -...-...-...-.-

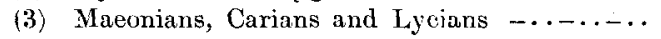

(4) Thracians and Paeonians $--\cdots--\cdots--\cdots$

used. Elsewhere ${ }^{80}$ he has some very instructive remarks about the difference between routes for commerce and for other purposes which should be borne in mind when one is tempted to a hasty conclusion as to one (and only one) way to reach a place. Naturally it all depends on what you want to transport.

Long ago Professor Myres pointed out the connexions between Cyprus and Hissarlik and suggested an overland route. Hissarlik combines 
European and Asiatic, Danubian and Cypriote elements in pottery, implements, bronze and copper. ${ }^{81}$ The recent discoveries have gone a good way towards confirming this view and give us milestones on the route.

Contemporary with the Balkan neolithic period was the second city at Troy with its face-urns, its jars with suspension holes, its white-filled incised pottery, its wealth of metal-copper and bronze and the golden royal treasure-as well as the continued use of stone, which bears witness to foreign trade extending from Melos to China, its northern type of megaron and the evidences of great prosperity of the city during its long occupation. ${ }^{82}$

An important point to be noted regarding strata II.-V. which succeeded the great second city after its destruction by fire is the possible indication of the first arrival of a fresh civilization before the end of Period V., when painted pottery makes its first appearance. ${ }^{83}$

The sixth city is of course contemporary with L. M. and was destroyed in the Trojan war. In the seventh stratum there are records of fusion of the successors of the older city with another wave of invaders. Early Greek geometric pottery is found with crude barbarous 'knob ware' and with metal axes, hammers, chisels, needles and rings which are neither Trojan nor Greek, but typically Danubian. These may perhaps be attributed to the Treres, a Thracian tribe, who with the Cimmerians crossed the Bosporus in post-Homeric times, probably about the eighth century. A mould for a battle-axe of Danubian type shows that these people were metalworkers and practised their art at Troy itself. ${ }^{84}$

If we turn next to the testimony of Homer we shall see that the valleys of the Strymon and the Axios belonged to the Paeonians who were numbered among the allies of the Trojans. The Map (Fig. 2) shows in graphic form the four lines which Dr. Leaf takes to 'represent the four trade routes which converged on 'Troy,' starting from the four groups of allies given in the 'Trojan catalogue. ${ }^{85}$

The three of these which lie in Asia Minor need only passing mention; they are (1) the Paphlagonians and the Halizones from far-away Alybe who dwelt along the shore of the Black Sea, tapped the country lying to the south and shipped their goods via the Bosporus and the Hellespont. ${ }^{86}$

(2) There were the Mysians and Phrygians, the near neighbours of the Trojans, who lived up in the back country and who had doubtless crossed from Thrace at a remote period. ${ }^{87}$

(3) There were the Maeonians, Carians and Lycians, who probably were traders rather than fighters and who followed a line up the coast inside the islands by what was known as the 'inner lead.' 88

(4) Another group of lines which led to Troy particularly concerns us.

81 Myres, J.A.I. Nov. 1897 ; Catalogue of Cyprus Museum, pp. 17, 18.

${ }^{82}$ Leaf, Troy, ch. iii. 60-80.

83 Ibid. p. 84.

${ }^{84}$ Leaf, Troy, pp. 102-112.
85 Ibid. p. 270.

${ }^{86}$ Ibid. pp. 278-296.

${ }^{87}$ Ibid. pp. 297-304.

88 Ibial. pp. 305-311. 
'But Akamas and Peiroos led the Thracians, even all them who are bounded by swift-flowing Hebrus.

'And Euphemos was captain of the war-like Kikones.'

'Pyraichmes led the Paeonians of the crooked bow from far-away Amydon, from the wide-flowing Axios, Axios whose water is the fairest that Hows upon the earth.' 89

In a word, they are Thracians bounded by the Hellespont, Paeonians from the Axios, and Kikones between them. No Thracian tribes are specified and no town named in the catalogue, but Peiroos, one of their leaders, comes from Ainos, the harbour at the mouth of the Hebrus and the obvious port for that valley, ${ }^{90}$ exactly the Maritza on which we found there were plentiful remains.

Next to them came the Kikones with no specific boundaries mentioned, but other evidence connects them with Mount Ismarus, which separated them from the Hebrus valley. It is not easy to say where was the ancient port: it was probably at Dede Agatch. ${ }^{91}$

The Paeonians, as Professor Macurdy ${ }^{92}$ has shown, originally occupied far more extensive territory than they did later when the Macedonians drove them back to the upper Axios. They doubtless extended from the Nestos to the Axios, including on the way the Strymon and the Pangaeus range. That they were people of great wealth and importance is clearly manifest, for they had the gold and silver mines of Pangaeus and rich fertile country for corn-growing. Probably a large part of what was later Macedonia was formerly inbabited by the Paeonians, whether they belonged to the Thracian or Illyrian stock. These I think, anyway, were branches of the same people from the Danube district. The Thracians are specially mentioned for their metal work, goblets, and great swords, and also for their white horses, which were famous from the time of Rhesus throughout classical antiquity.

If we include in Paeonian territory the mouths of the Axios and Strymon, we should undoubtedly connect them by a road via Lake Bolbe cross the top of Chalcidice. From Troy the sea route to Salonica would have been both long and dangerous, as Xerxes learned to his cost. From the mouth of the Strymon the route to Troy might be overland via the coast towns already mentioned, or across the sea by a straight south-east course, or by the stepping-stones of Thasos, Samothrace, Imbros and Lemnus. This connexion seems more than likely in view of Professor Macurdy's researches, which are based chiefly on names and religion.

The Dardanians gave their name to the Dardanelles and seem to have followed the route to Troy via Samothrace, the island which Pausanias says had originally been called Dardania. ${ }^{93}$ Dardania-Paeonia was from early times an important commercial centre, right on the trade-route from the Danube, and much metal must have passed that way. In historic times the

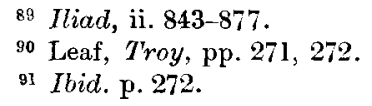

92 Macurdy, in I'ransactions A m. Phit. Asso. xlvi. 1915, pp, 119-128.

${ }^{\prime 3}$ I bid. p. 122. 
coinage of that region was remarkably rich, as the researches of M. Svoronos have shown. ${ }^{94}$

Hardly enough excavation has taken place to prove much about remains, but there must have been some contact as the references to Lemnos and Imbros in the lliad show. Moreover, Lemnos kept up relations with both 'Trojans and Greeks; Dr. Leaf describes the Lemnian attitude to the Greeks as one of 'friendly neutrality'; it was a base of supplies and a market for slaves, but also maintained commercial relations with the Trojans, acting as brokers for the ransom of important prisoners. ${ }^{95}$ Maybe its position was like that of the present Switzerland, which has had to keep on friendly terms with both sides in the war.

These converging lines indicate that Troy was a meeting place for people from both sides of the Aegean, and that the whole Hellespontine district must be regarded as a geographical unit. One is tempted to conclude that at one time all roads led to Troy whether they were land routes or over the wet sea ways. Dr. Leaf's view, now familiar to all scholars, is that Troy's wealth was due to her control of the Dardanelles, and that with the fall of Troy and the opening of the Straits to the Greeks her glory departed. This would give a reasonable explanation of why she never rose again to any importance after the destruction of the Homeric city. The fact that the book Troy, a Study in Homeric Geography, was published in 1912 will show that this suggestion was based on independent evidence and in no wise influenced by recent events, which have demonstrated so clearly the infinite importance of the control of the Dardanelles.

And it was not only the Dardanelles which contributed to Troy's dominant position. Salonica, that other strategic point of such value to the Allies at first during a long period of apparent inactivity and then as a base for a great movement northward which reached to the Danube and beyond--Salonica seems also to have had close connexions with Troy.

We find that Troy was but slightly influenced by the Aegean civilization, and if we believe that the Greeks of history represent the fusion of northern or Achaean conquerors with their Mycenaean subjects, and that the northern element was Greek or Hellenic par excellence, then we may not only accept Professor Bury's suggestion that the Trojans were Greeks, ${ }^{96}$ but also, paraphrasing Hibernis ipsis Hiberniores, we may say that they were more Greek than the Greeks themselves.

This would be of course but an absurd half truth, for to Troy as to Hellas many elements contributed. We do not know what was the original stock at Troy, but we know that the Danubian element came early and came often, that there was connexion with Cyprus and with the Anatolian districts, but that the Aegean influence was temporary and apparently rather superficial, and that after it had passed the old European kinsmen once more poured into the city of their ancestors.

Ida Carleton Thallon.

91 Ibid. p. 125.

${ }_{95}$ Leaf, Troy, p. 268.

${ }^{96}$ Bury, Quarterly Review, July, 1916. 